\title{
Fuzzy Logic Controller Design for Voltage, Frequency, Current and Power Control of Three-phase Distributed Generation Based Islanded Microgrid
}

\author{
S.A. Dola ${ }^{1}$, J. Mondal2,*, A.A. Khandoker ${ }^{3}$, S. Shahriar ${ }^{3}$, M.D. Arifuzzamann, F.R. Badal ${ }^{1}$, \\ N. Mondol ${ }^{5}$, S.K. Das ${ }^{1}$ \\ ${ }^{1}$ Rajshahi University of Engineering \& Technology, Rajshahi-6204, Bangladesh \\ ${ }_{2}^{2}$ Bangabandhu Sheikh Mujibur Rahman Science \& Technology University, Gopalganj-8100, Bangladesh \\ ${ }^{3}$ American International University Bangladesh, Bangladesh \\ ${ }^{4}$ Varendra University, Rajshahi, Bangladesh \\ ${ }^{5}$ Khulna University of Engineering \& Technology, Khulna, Bangladesh
}

(Received 11 January 2021; revised manuscript received 14 June 2021; published online 25 June 2021)

\begin{abstract}
Today's clean technologies related to microgrids are approaching towards the smart nanogrid system. It fulfils the demand of the electricity throughout the world by proper using of renewable energy sources and energy storage systems. Still, the microgrid (MG) power plant control has enriched to a level that it will require complicated and smooth control in the grid interaction including distributed islanding operation. The load dynamics and uncertainties are the common issues which hampers the frequency, voltage and power profile of the MG that is responsible to damage the load and power system. The design of robust fuzzy logic controller (FLC) has been proposed in this research article to regulate the performances of three-phase islanded MG. The performance of the proposed FLC has been examined under different loading condition whose robustness has been evaluated under faulty condition. The investigated performances of the MG ensure high tracking and robust performance of the proposed FLC.
\end{abstract}

Keywords: Current and power control, Fuzzy logic controller (FLC), Islanded microgrid.

DOI: $10.21272 /$ jnep.13(3).03031

PACS numbers: 07.05.Tp, 07.07.Tw

\section{INTRODUCTION}

Electricity generation systems all over the world are largely dependent on fossil fuels like coal, diesel, and natural gas. The increasing energy demands of modern civilization are reducing fossil fuel reserves. Moreover, the burning of fossil fuels produces a tremendous amount of carbon dioxide, sulphur dioxide, and nitrogen dioxide, which are known as greenhouse gases [1-4]. Therefore, to reduce the consumption of fossil fuels as well as greenhouse gases and deliver proper power to any location, the development of MGs has been pursued [5-12]. Moreover, the dependency of the world on MGs is promoting due to the developed reliability, sustainability, and utility and lower required investment of MGs [13-16].

When disturbances occur in the main grid, such as a fault, contingencies, and voltage and power collapses, the MG is decoupled from the utility grid and operates in a standalone mode. This mode of operation is known as islanded mode [17].

Wind or sun light is the prime mover for the MG to generate energy whose variable nature is responsible to deviate the performance of the MG. Again, load dynamics, fault or uncertainties hamper the nominal operation of the MG [1-5].

Ref. [2] investigated the integration and control approach of single- and three-phase islanded MG by accounting its voltage and current control. The design of improved hierarchical control approach consisting of primary, secondary and tertiary control loop has been proposed to regulator the voltage and frequency of the islanded MG [18]. Ref. [19] investigated the design of
PID controller to stable the power and frequency deviation of the islanded MG.

The aforementioned control approaches can regulate the performance of MG efficiently but the lower bandwidth, phase- and gain margin are the limitations of these controllers. The aim of this research article is to design a high performance FLC to enhance the voltage, current and power profile of the three-phase islanded MG. The usefulness of the FLC has been investigated against load dynamics and uncertainties.

The remaining article is arranged as follows: system modeling is discussed in Section 2 while Section 3 proposes the control technique for MG. Performance analysis and conclusion is carried out in Section 4 and 5 .

\section{THREE-PHASE ISLANDED MICROGRID DESIGN}

\subsection{Circuit Diagram for the Three-Phase Islanded MG}

The only basic control loop is also observed as voltage controller which preserves the trailing execution. An error is produced by comparing the grid voltage with the reference voltage to justify this voltage controlling method. The developed error is fed to the voltage controller which generates reference inductor current $\left(\tilde{I}_{L}\right)$. The current controller passes this excited current flow that initiates the duty ratio $\alpha$. By controlling this particular duty ratio $\alpha$, improved and desired trailing performances are ensured for the microgrid systems against various load dynamics and harmonics.

*jmondal.bsmrstu@gmail.com

The results were presented at the International Conference on Innovative Research in Renewable Energy Technologies (IRRET-2021) 


\subsection{Governing Equations for Three-Phase System}

The 3-phase MG can be modeled based on Fig. 1 as

$$
\begin{gathered}
\breve{V}_{t, a b c}=L_{t} \frac{d \breve{I}_{t, a b c}}{d t}+R_{t} \check{I}_{t, a b c}+\breve{V}_{a b c} \\
\frac{d \check{I}_{t, a b c}}{d t}=-\frac{R_{t}}{L_{t}} \check{I}_{t, a b c}+\frac{1}{L_{t}} \breve{V}_{t, a b c}-\frac{1}{L_{t}} \breve{V}_{a b c} \\
\frac{d \breve{V}_{a b c}}{d t}=\frac{1}{c_{t}} \check{I}_{t, a b c} .
\end{gathered}
$$

Converting (2.2) and (2.3) into $d q$ frame, the dynamical equations are expressed as follows:

$$
\begin{gathered}
\frac{d \check{I}_{t, d q}}{d t}=-j \omega_{\mathrm{o}} \check{I}_{t, d q}-\frac{R_{t}}{L_{t}} \check{I}_{t, d q}+\frac{1}{L_{t}} \breve{V}_{t, d q}-\frac{1}{L_{t}} \breve{V}_{d q}, \\
\frac{d \breve{V}_{d q}}{d t}=-j \omega_{\mathrm{o}} \breve{V}_{d q}+\frac{1}{C_{t}} \check{I}_{t, d q} .
\end{gathered}
$$

The above equations can be written as

$$
\frac{d}{d t} \breve{V}_{d}=\omega_{\mathrm{o}} \breve{V}_{q}+\frac{1}{c_{t}} \check{I}_{t, d}
$$

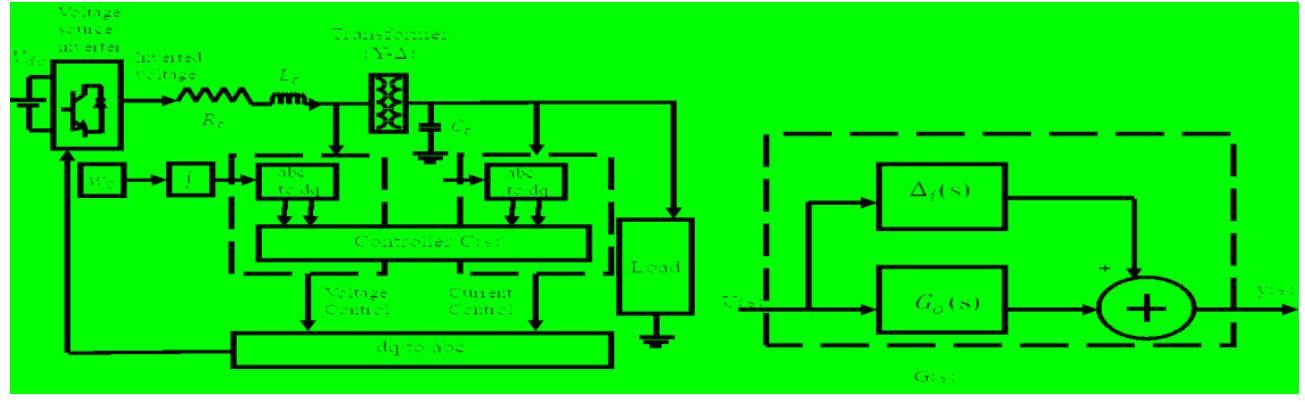

Fig. 1 - Control structure of three-phase islanded MG

$$
\begin{gathered}
\frac{d}{d t} \breve{V}_{q}=-\omega_{\mathrm{o}} \breve{V}_{d}+\frac{1}{C_{t}} \breve{I}_{t, q}, \\
\frac{d}{d t} \breve{I}_{t, d=}-\frac{1}{L_{t}} \breve{V}_{d}-\frac{R_{t}}{L_{t}} \breve{I}_{t, d}+\omega_{\mathrm{o}} \breve{I}_{t, q}+\frac{1}{L_{t}} \breve{V}_{t, d}, \\
\frac{d}{d t} \breve{I}_{t, q=}-\frac{1}{L_{t}} \breve{V}_{q}+\omega_{\mathrm{o}} \breve{I}_{t, d}-\frac{R_{t}}{L_{t}} \breve{I}_{t, q}+\frac{1}{L_{t}} \breve{V}_{t, q} .
\end{gathered}
$$

Now using (2.8) to (2.9), we consider $G p(s)=$ $C p(s I-A p)^{-1} B p+D p$, where

$$
\begin{gathered}
A_{p}=\left[\begin{array}{cccc}
0 & \omega_{0} & \frac{1}{C_{p t}} & 0 \\
-\omega_{0} & 0 & 0 & \frac{1}{C_{p t}} \\
-\frac{1}{L_{t t}} & 0 & \frac{R_{s t}}{L_{t t}} & \omega_{0} \\
0 & \frac{1}{L_{t t}} & \omega_{0} & \frac{R_{s t}}{L_{t t}}
\end{array}\right], B_{p}=\left[\begin{array}{cc}
0 & 0 \\
0 & 0 \\
\frac{1}{L_{t t}} & 0 \\
0 & \frac{1}{L_{t t}}
\end{array}\right] \\
C_{p}=\left[\begin{array}{cccc}
1 & 0 & 0 & 0 \\
0 & 1 & 0 & 0
\end{array}\right] \text { and } D_{p}=0,
\end{gathered}
$$

where the state vector $x=\left[\begin{array}{llll}\breve{V}_{d} & \breve{V}_{q} & \check{I}_{t, d} & \check{I}_{t, q}\end{array}\right]^{T}$; input vector $u=\left[\begin{array}{lll}\breve{V}_{t, d} & \breve{V}_{t, q}\end{array}\right]^{T}$ and the output vector $y=\left[\begin{array}{ll}\breve{V}_{d} & \breve{V}_{q}\end{array}\right]$. Parameter values for three-phase MG has been inserted in Table 1.

Table 1 - Three-phase microgrid parameters

\begin{tabular}{|c|c|}
\hline Description & Value \\
\hline DC-bus voltage $\left(V_{d c}\right)$ & $300 \mathrm{~V}$ \\
\hline Capacitive filter $\left(C_{p}\right)$ & $15 \mu \mathrm{F}$ \\
\hline Inductive filter $\left(L_{t}\right)$ & $2 \mathrm{mH}$ \\
\hline Line resistance $\left(R_{L}\right)$ & $0.45 \Omega$ \\
\hline Consumer $(R)$ & $40 \Omega$ \\
\hline Damping constant $(\zeta)$ & 0.7 \\
\hline Resonant frequency $\left(\omega_{n}\right)$ & 5700 \\
\hline
\end{tabular}

\section{CONTROLLER DESIGN}

The range for both the inputs (IN) is selected from -600 to 600 . Also, the ranges for the three different membership functions are shown in Fig. 2. The functions are defined as $\mathrm{mf} 1, \mathrm{mf} 2, \mathrm{mf} 3$, respectively. Each membership function has a range as $\operatorname{mf} 1[-600-450-300]$;

mf2 [- 30000300$]$;

mf3 [300 450 600].

The range for both the outputs (OT) is selected from -2 to 2 . Also, the ranges for the three different membership functions are shown in Fig. 3. The functions are defined as $\mathrm{mf} 1, \mathrm{mf} 2, \mathrm{mf} 3$, respectively. Each membership function has a range as,

$\mathrm{mf} 1[-2-1.4-0.8]$;

$\mathrm{mf2}\left[\begin{array}{lll}-0.8 & 0 & 0.8\end{array}\right]$;

mf3 [0.8 1.4 2].

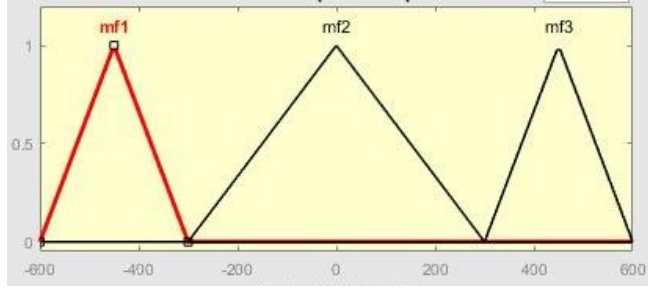

Fig. 2 - Triangular input membership functions of FLC for Input 1 and Input 2

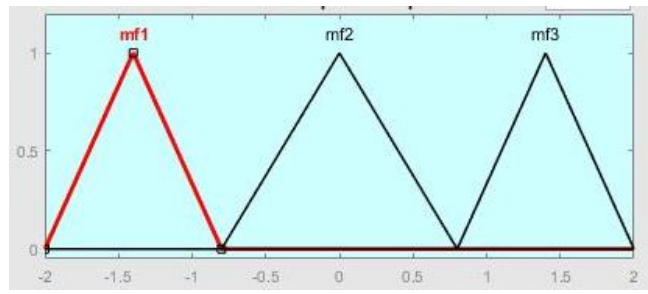

Fig. 3 - Triangular output membership functions for Output 1 and Output 2 

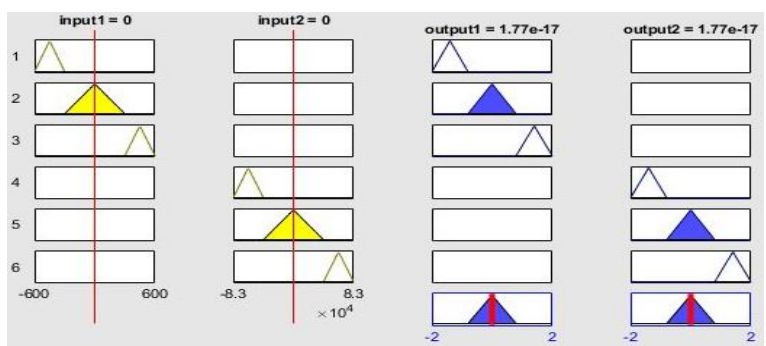

Fig. 4 - IN and OT rule viewer

The rule editor window represents the assigned rules in verbose form in Fig. 4 . It shows the overall view on how to set the rules efficiently. The conditions are:
If IN 1 is $\mathrm{mf} 1$ then OT 1 is $\mathrm{mf} 1$;

If IN 1 is $\mathrm{mf} 2$ then OT 1 is $\mathrm{mf} 2$;

If IN 1 is mf 3 then OT 1 is $\mathrm{mf} 3$;

If IN 2 is $\mathrm{mf} 1$ then OT 2 is $\mathrm{mf} 1$;

If IN 2 is $\mathrm{mf} 2$ then OT 2 is $\mathrm{mf} 2$;

If IN 2 is mf3 then OT 2 is $\mathrm{mf} 3$.

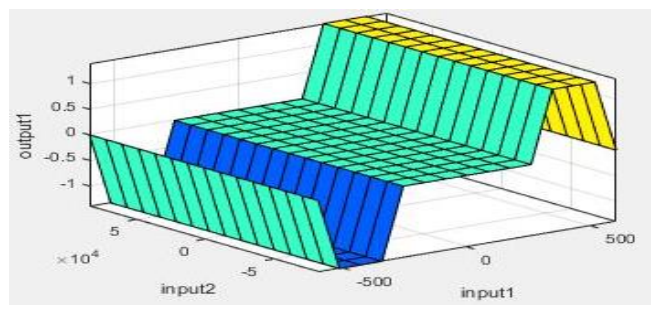

Fig. 5 - FLC surface simulation

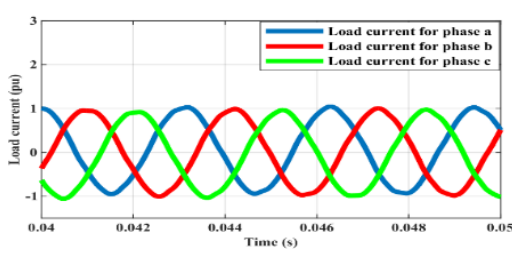

a

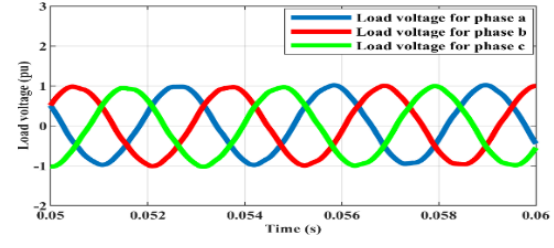

b

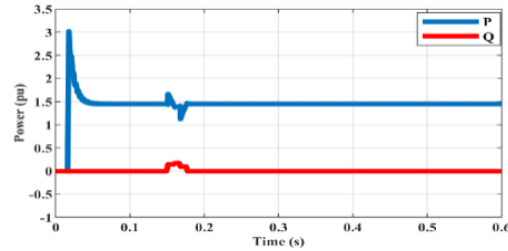

c

Fig. 6 - Control of current (a), voltage (b), and power (c) for balance load

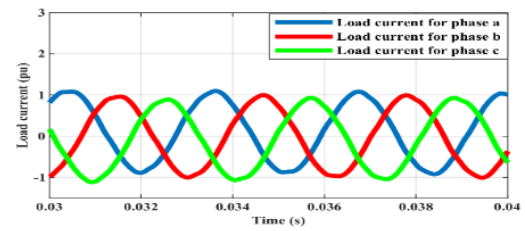

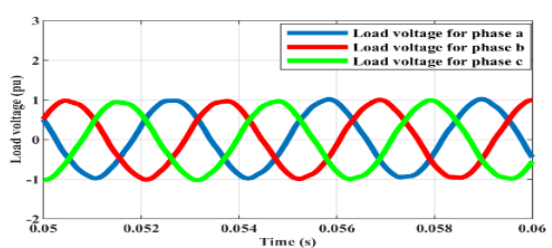

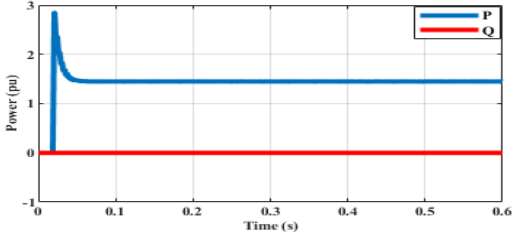

Fig. 7 - Control of current (a), voltage (b), and power (c) for consumer load

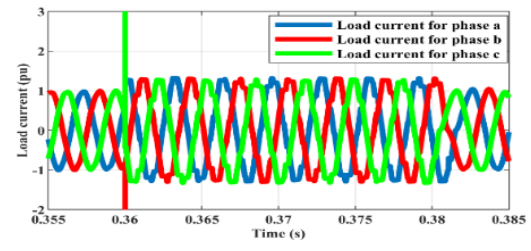

a

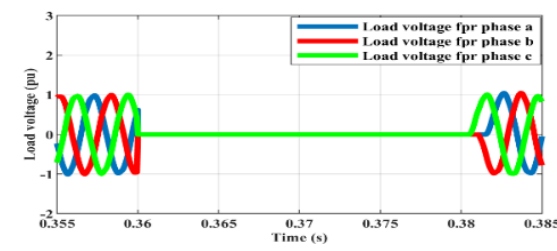

$\mathrm{b}$

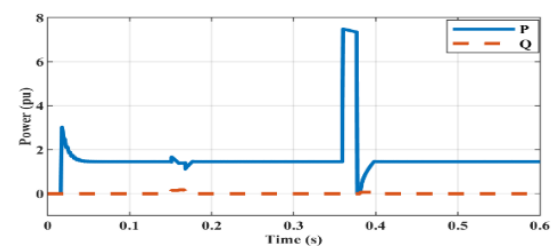

$\mathrm{c}$

Fig. 8 - Control of current (a), voltage (b), and power (c) during fault condition for balance load

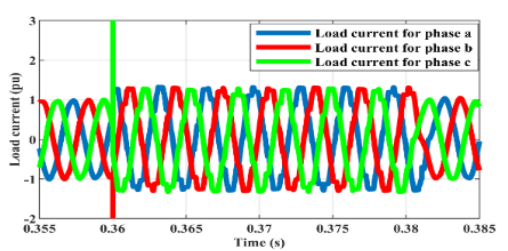

a

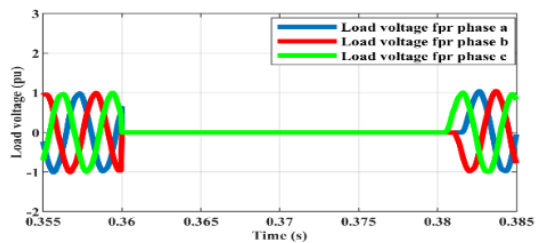

b

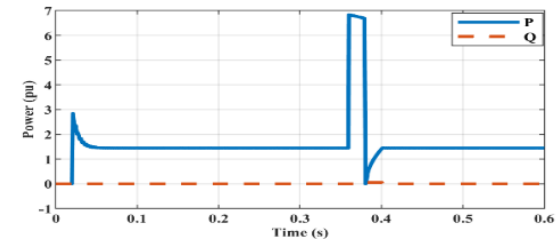

Fig. 9 - Control of current (a), voltage (b), and power (c) during fault condition for consumer load

The final IN and OT values are set at 0 and $1.77 \mathrm{e}$ 17 (approximately 0) in Fig. 5. The values of the IN and OT functions are set according to the predefined rules. The result produces the signal for controlling the voltage as an outcome.

\section{PERFORMANCE EVALUATION}

Different types of load have been used to exam the performance of the FLC approach. A resistive load has been used to construct the balanced load having $3 \mathrm{~kW}$ active power and $60 \mathrm{~V}$ phase-phase voltage which is 
switched on from $t=0.3 \mathrm{~s}$ to $0.31 \mathrm{~s}$. The performance of the FLC under balanced load has been investigated in Fig. 6 that ensures better performance of the controller.

Fig. 7 exhibits the controller performance against consumer load that shows smooth performance. The robustness analysis of the FLC controller has been analyzed in this paper against faulty condition. A fault is applied from $t=0.36 \mathrm{~s}$ to $0.38 \mathrm{~s}$. The proposed control approach overcome this fault and stable the response by minimizing the performance deviations as shown in Fig. 8 and Fig. 9.

\section{REFERENCES}

1. J.A.P. Lopes, C.L. Moreira, A.G. Madureira, IEEE Trans. Power Syst. 21 No 2, 916 (2006).

2. F.R. Badal, P. Das, S.K. Sarker, S.K. Das, Prot. Cont. Mod. Power Syst. 4 No 8, 1 (2019).

3. S.K. Sarker, F.R. Badal, S.K. Das, M. Yuan, 3rd International Conference on Electrical Information and Communication Technology (EICT), 1 (2017).

4. B.V. Rajanna, G. Joga Rao, S.K. Shrivastava, Int. J. Power Electron. Drive Syst. 7 No 3, 723 (2016).

5. S.K. Sarker, F.R. Badal, S.K. Das, Int. J. Dynam. Control 6 No 3, 1207 (2018).

6. S.K. Sarker, F.R. Badal, P. Das, S.K. Das, Asian J. Control 21 No 4, 2114 (2019).

7. C. Natesan, S.K. Ajithan, S. Chozhavendhan, A. Devendhiran, Int. J. Ren. Ener. Res. 5 No 2, 334 (2015).

8. M.A. Rahman, S.K. Sarkar, F.R. Badal, S.K. Das, International Conference on Advancement in Electrical and Electronic Engineering (ICAEEE), 1 (2018).

9. F.R. Badal, S.K. Sarker, S.K. Das, 4th International Conference on Electrical Engineering and Information \& Communication Technology (iCEEiCT), 142 (2018).

\section{CONCLUSIONS}

Variable nature of the prime mover, load dynamics and uncertainties are the critical factors which hamper the performance of the islanded microgrid that damages the load as well as power system. An improved design of FLC controller has been designed in this paper to overcome these problems and improve the system performance. The proposed control technique exhibits better tracking performance against load dynamics. The performance against fault ensures higher tracking and robust performance of the proposed FLC approach.

10. H. Mahmood, D. Michaelson, J. Jiang, IEEE Trans. Power Electron. 30 No 12, 7215 (2015).

11. S.K. Das, D. Datta, S.K. Sarker, S.R. Fahim, M.R.I. Sheikh, F.R. Badal, 2nd International Conference on Smart Power \& Internet Energy Systems (SPIES), 299 (2020).

12. C.N. Rowe, T.J. Summers, R.E. Betz, D.J. Cornforth, T.G. Moore, IEEE Trans. Power Electron. 28 No 8, 3747 (2012).

13. K. De Brabandere, B. Bolsens, J. Van Den Keybus, A. Woyte, J. Driesen, R. Belmans, IEEE Annu. Power Electron. Spec. Conf. 4, 2501 (2004).

14. A. Engler, Applicability of Droops in Low Voltage Grids, (2005).

15. J.Y. Kim, H.M. Kim, S.K. Kim, J.H. Jeon, H.K. Choi, Energies 4 No 9, 1443 (2011).

16. X. Ding, Z. Qian, S. Yang, B. Cui, F. Peng, Conf. Proc. - IEEE Appl. Power Electron. Conf. Expo. - APEC, 1145 (2007).

17. Y. Lee, S. Park, M. Lee, C. Brosilow, AIChE J. 44 No 1, 106 (1998).

18. Y.A.R.I. Mohamed, A.A. Radwan, IEEE Trans. Smart Grid 2 No 2, 352 (2011).

19. M.A. Hossain, H.R. Pota, Int. J. Renew. Energ. Res. 5 No 3, 806 (2015).

\title{
Конструкція контролера нечіткої логіки для управління напругою, частотою, струмом та потужністю ізольованої мікромережі на основі трифазної розподіленої генерації
}

\author{
S.A. Dola ${ }^{1}$, J. Mondal ${ }^{2}$, A.A. Khandoker ${ }^{3}$, S. Shahriar ${ }^{3}$, M.D. Arifuzzaman ${ }^{4}$, F.R. Badal ${ }^{1}$, \\ N. Mondol ${ }^{5}$, S.K. Das ${ }^{1}$
}

${ }^{1}$ Rajshahi University of Engineering \& Technology, Rajshahi 6204, Bangladesh

2 Bangabandhu Sheikh Mujibur Rahman Science \& Technology University, Gopalganj 8100, Bangladesh

${ }^{3}$ American International University Bangladesh, Bangladesh

4 Varendra University, Rajshahi, Bangladesh

${ }^{5}$ Khulna University of Engineering \& Technology, Khulna, Bangladesh

\begin{abstract}
Сьогоднішні екологічно чисті технології, пов'язані з мікромережами, наближаються до розумної системи наномереж. Вона задовольняе попит на електроенергію у всьому світі шляхом належного використання відновлюваних джерел енергії та систем накопичення енергії. Проте, управління електростанцією з використанням мікромереж перейшло на рівень, який вимагає складного і плавного контролю у взаємодії з мережею, включаючи розподілену операцію ізоляції. Динаміка навантаження і похибки е загальними проблемами, що впливають на профіль частоти, напруги та потужності мікромережі, яка є відповідальною за пошкодження навантаження та системи енергопостачання. У статті запропоновано конструкцію надійного контролера нечіткої логіки (FLC) для регулювання характеристик трифазної ізольованої мікромережі. Характеристики запропонованого FLC досліджували за різних умов навантаження, надійність яких оцінювали у стані несправності. Досліджувані характерис тики мікромережі забезпечують високе відстеження та надійну роботу запропонованого FLC.
\end{abstract}

Ключові слова: Управління струмом та потужністю, Контролер нечіткої логіки (FLC), Iзольована мікромережа. 